\title{
DESCRIPTION OF THE FEMALE OFF GRIMPOTEUTHIS BRUUNI VOSS, 1982
}

\section{DESCRIPCION DE LA HEMBRA GRIMPOTEUTHIS BRUUNI VOSS, 1982}

\author{
Marco A. Vega Petkovic \\ Departamento Ciencias Básicas, Universidad Santo Tomas, \\ Héroes de la Concepción 2885. Iquique, Chile. mvegap@santotomas.cl
}

\begin{abstract}
This study mentions the first female of Grimpoteuthis bruuni collected in fishery of crustaceous of Chilean water. With base in the morphology, the female can be separated clearly from the males of the same species and another species of the genus Grimpoteuthis. The specimen this deposited in the collection of cephalopods of the National Museum of Natural History of Santiago of Chile.
\end{abstract}

Voss (1982) described for first time Grimpoteuthis brunni, a new species of cirrate finned octopod from the Southeastern Pacific, on collected material in front of Antofagasta, Chile (23⒋' S, 70³4'W) and deposited in National Museum of Natural History, Smithsonian Institution, Washington D.C., United States (USNM). However, hitherto there is not new antecedent of this species in Chilean water.

This short communication inform of a mature female of $28 \mathrm{~mm}$ mantle length collected in the crustacean trawl fishery between 1996 and 1999 mainly around $400 \mathrm{~m}$ depth on continental slope off Chile between $21^{\circ} 34^{\prime}-38^{\circ} 30^{\prime} \mathrm{S}$ deposited in National Museum of Natural History, Santiago of Chile (MNHN).

The female can be separated of other species of the genus Grimpoteuthis based on consistence gelatinous with a body more width that length, 1.5 to 2 times

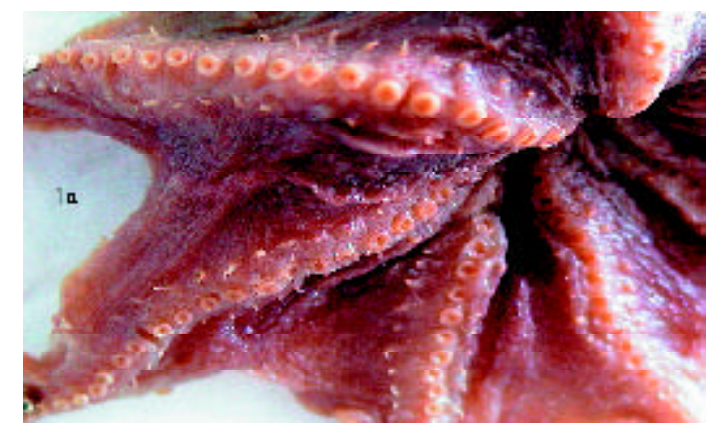

more short that arms. The fourth pair of arms is the longer. Fins more straits that body, situates more lastly $33 \%$ or less that ocular distance. The shell is broadly U-shaped. Eyes large. Gills with six lamellae. Without suckers enlarged on all arms (Figure 1).

Also can be separated of males of the same species already that they have 2 suckers enlarged on part proximal (diameter 5 to $8 \%$ of mantle length) and 3 to 4 distal on arms.

\section{BIBLIOGRAPHY}

Voss, GL. 1982. Grimpoteuthis bruuni, a new species of finned octopod (Octopoda: Cirrata) from the Southeastern Pacific. Bulletin of Marine Science, 32(2): 426- 433.

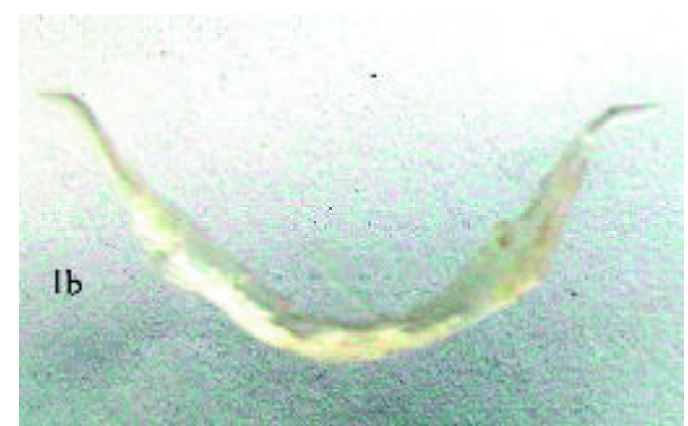

Figure. 1a. Grimpoteuthis bruuni, oral vista. 1b. Shell in form of U.

Figura. 1a. Grimpoteuthis bruuni, vista oral. 1b. Concha en forma de U. 